CASE NOTE

\title{
TP $v$ MINISTER OF HOME AFFAIRS (SENTENCE NO 9140, 22 APRIL 2014) (TRIBUNAL OF ROME)
}

\author{
PAOLO FARCI*
}

TABLE OF CONTENTS

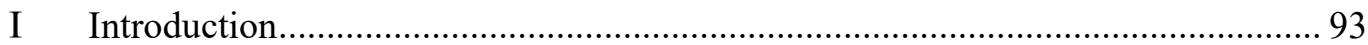

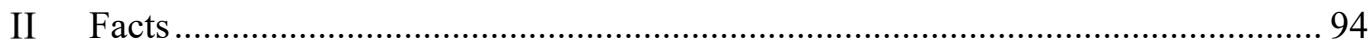

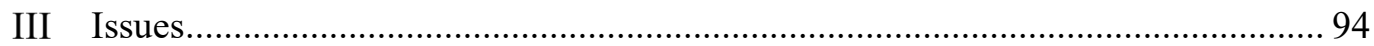

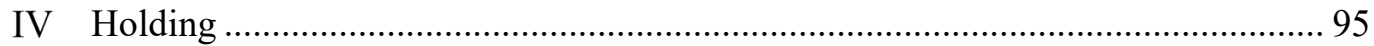

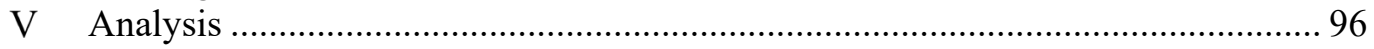

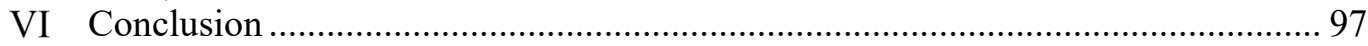

\section{INTRODUCTION}

There are two procedures to determine statelessness in Italy. One is under the competence of the Ministry of the Interior, which can certify, pursuant to the administrative procedure under art 17 of Decree of the President of the Republic No 572,1 the statelessness of applicants who are able to show: (a) a birth certificate; (b) documentation relating to residence in Italy; and (c) any document suitable for demonstrating statelessness. The other procedure is under the competence of the civil courts. ${ }^{2}$ This judicial procedure does not require applicants to provide evidence of their lawful status or residence and thus, it is the route followed by most stateless persons. ${ }^{3}$ The present case, TP $v$ Minister of Home Affairs,${ }^{4}$ concerns the latter route to statelessness determination and involves TP's application to the Tribunal of Rome to recognise his status as a stateless person. This case represents an unusual example of a court using its inquisitorial powers to seek evidence in support of its ruling and, as such, it set a judicial precedent, which can assist the determination of similar proceedings. It was also the first time

* Paolo Farci is an Italian lawyer from Florence specialising for over 25 years in statelessness. $\mathrm{He}$ is a member of the Statelessness Table (United Nations High Commissioner for Refugees) and a member of the European Network of Statelessness. He is responsible for the Trainingof-Trainers for the judiciary for the JUSTROM-Italy program of the Council of Europe and the European Union and is an external collaborator at the Ministry of the Interior-Department for Civil Liberties and Immigration. He is the author of two books on the subject of statelessness: Paolo Farci, Apolidia (Giuffrè 2012) and Paolo Farci, I Migranti Apolidi di Lampedusa: Alle Vittime dell'Immigrazione Clandestina (Giuffrè 2014). He can be contacted at farcipl@avvocatopaolofarci.it.

1 Decree of the President of the Republic No 572 of 12 October 1993 'Implementing Regulation to the Law No 91 of 5 February 1992' (1994) 135(2) Gazzetta Ufficiale 3, art 17 (Italy).

2 MJCA v Prefecture - Territorial Office of the Government of Bologna (First Civil Section, Sentence No 28873, 9 December 2008) (Supreme Court of Cassation) (Italy).

3 Decree of 17 February 2017, No 13 'Urgent Provisions for the Acceleration of Proceedings in the Field of International Protection, As Well As for the Fight against Illegal Immigration', 158(90) Gazzetta Ufficiale 1 (Italy).

$4 \quad$ TP v Minister of Home Affairs (Sentence No 9140, 22 April 2014) (Tribunal of Rome) ('TP $v$ Minister of Home Affairs'). 
that a court found the Government of India's practice regarding the treatment of Tibetans born in India to Tibetan parents amounted to a denial of nationality. ${ }^{5}$

\section{FACTS}

TP is a person of Tibetan origin (both parents were born in Tibet). ${ }^{6}$ Although he was born, resided and legally attended school in India until his departure for Italy in 2007, the authorities of India never recognised him as an Indian citizen nor as a refugee or stateless person. ${ }^{7}$ Theoretically, TP would be entitled to acquire Indian nationality under Indian nationality law. ${ }^{8}$ However, the Indian authorities issued TP with an identity certificate in 2003, stating he was of Tibetan nationality. ${ }^{9}$ Additionally, TP did not enjoy rights typically afforded to Indian nationals including right to vote and work for the government. ${ }^{10}$

In 2008, the Consulate General of India in Milan refused to recognise TP as an Indian national or issue a passport. Instead, they confirmed TP's Tibetan nationality. ${ }^{11}$ Consequently, TP applied to the Tribunal of Rome for recognition of his status as a stateless person.

\section{ISSUES}

Under the 1954 Convention Relating to the Status of Stateless Persons ('1954 Convention'), as ratified by Italy, the assessment of statelessness requires checking whether a person 'is not considered as a national by any State under the operation of its law'. ${ }^{12}$

Thus, the question for Tribunal of Rome in the present case was whether the appellant was a citizen of either country they had connections with, namely India or Italy. ${ }^{13}$ If the applicant was a citizen of India, the Tribunal also had to determine whether the treatment by the Indian authorities was essentially equivalent to refusing the individual protections or prerogatives linked to nationality. ${ }^{14}$

5 As I was the lawyer representing the applicant, this case note is partly based on the court decision and partly on my experience and knowledge of the claim.

6 ibid 3 .

7 ibid. India has never acceded to the following conventions: Convention Relating to the Status of Refugees, opened for signature 31 August 1951, 189 UNTS 137 (entered into force 22 April 1954); Convention Relating to the Status of Stateless Persons, opened for signature 23 September 1954, 360 UNTS 117 (entered into force 6 June 1960) ('1954 Convention').

8 TP $v$ Minister of Home Affairs (n 4) 3.

9 ibid.

10 India: Information on Tibetan Refugees and Settlements' (Query No IND03002.ZNY, United States Bureau of Citizenship and Immigration Services 30 May 2003) $<$ https://www.refworld.org/docid/3f51f90821.html>.

11 TP v Minister of Home Affairs (n 4) 3.

121954 Convention (n 7) art 1.

13 TP v Minister of Home Affairs (n 4) 2-3.

14 ibid. 


\section{HOLDING}

The Tribunal of Rome ruled that TP is an Indian citizen according to Indian citizenship rules. ${ }^{15}$ However, TP was not recognised as a national in India. The Government of India's actions reflected a common practice concerning individuals born in India to Tibetan refugee parents, as is apparent in several other cases examined by Canadian and United States jurisprudence. ${ }^{16}$ The Indian Consulate in Milan refused to recognise TP's Indian citizenship and passport following a new application in March 2008. ${ }^{17}$ The Consulate issued a certificate which determined TP's status as a Tibetan national, meaning that TP could not avail himself of the rights afforded to Indian nationals. ${ }^{18}$ This proved that TP was not recognised as a national and was, therefore, stateless. ${ }^{19}$ The Tribunal of Rome stated that 'the attitude of the Republic of India towards the applicant is equivalent in all respects to a denial of citizenship'. ${ }^{20}$ It added that it was not important to investigate the causes or consequences of such conduct, which were summarised as

the impossibility of the applicant being recognised as holding the citizenship of the country in which he was born and with which he has developed significant elements of connection, with the consequence that is impossible [for them] to enjoy [their] relative rights. ${ }^{21}$

The conditions for TP to obtain Indian citizenship by naturalisation, as referred to in s 6 (Third Schedule) (c) and (d) of the Indian Citizenship Act, 1955, are not met. Persons born in India between 26 January 1950 and 1 July 1987, which includes TP, cannot undergo any registration procedure to obtain Indian citizenship because the acquisition of nationality occurred automatically upon their birth in India, under s 3 of the same $A c t .{ }^{22}$

In the Italian state where TP currently resides, the Law of 5 February 1992, No 91 (New Rules on Citizenship) establishes the procedure for acquiring Italian

15 The procedure for acquiring Indian citizenship by birth pursuant to s 3 of the Indian Citizenship Act No 57 of 1955 (India) ('Indian Citizenship Act, 1955') does not require any application from the person born in India (or from his/her parents) to obtain it. Until the date of entry into force of the Citizenship (Amendment) Act No 6 of 1986 (India) on 1 July 1987, anyone who was born in India on or after 26 January 1950 and before 1 July 1987, became an Indian citizen automatically as a result of their birth in Indian territory: see Namgyal Dolkar v Ministry of External Affairs [2010] WP(C) 12179/2009 (High Court of Delhi); Rashtriya Mukti Morcha v Union of India (2007) DLT 195 (High Court of Delhi).

16 Namgyal Tenzin v United States Asylum Office of Immigration and Naturalisation (Brief No A78-359-240, Executive Office of Immigration Review in San Francisco 5 May 2003); India: 1) Legal Status of Tibetan Refugees; 2) Rights of Tibetans to Indian Nationality (Query No IND11239, Immigration and Refugee Board of Canada 1 July 1992) $<$ https://www.refworld.org/docid/3ae6aab124.html >: "According to the High Commission of India in Ottawa, Tibetan refugees are not entitled to acquire Indian nationality, even if they were born in India'.

17 TP v Minister of Home Affairs (n 4) 3.

18 ibid.

19 AA v Ministero dell'Interno (First Civil Section, Sentence No 14918, 28 June 2007) (Supreme Court of Cassation) (Italy) ('Sentence No 14918'); Case 1757/2009 (First Civil Section, 5 March 2010) (Tribunal of Lecce) (Italy); Decreto 5 Marzo 2003 (2005) 128(4) Il Foro Italiano 1283 (Tribunal of Milan) (Italy) ('Decreto 5 Marzo 2003').

20 TP $v$ Minister of Home Affairs (n 4) 3.

21 ibid.

22 Indian Citizenship Act, 1955 (n 15). 
citizenship. ${ }^{23} \mathrm{TP}$ has not acquired Italian citizenship because his is not married to an Italian citizen, does not have an Italian father or mother, nor has he acquired Italian citizenship by filiation or according to any other grounds of acquisition provided for by law. He does not even qualify for naturalisation.

Finally, the Tribunal stated that no other state considered TP a citizen, given that Tibet has not existed as an autonomous geopolitical entity for many decades. ${ }^{24}$

\section{ANALYSIS}

This case aligns with recent Italian case law, which attributes stateless status to those who do not have the citizenship of any of the states with which they have maintained relevant relationships. ${ }^{25}$ This approach limits the evidential investigation to two fundamental elements: the non-acquisition or loss of citizenship of the state of origin and the failure to acquire that of the state (or states) of residence or domicile.

With this in mind, the Tribunal of Rome tried to overcome the probative difficulties of showing negative proof of TP's statelessness by using all available means, including the presumptions set out in the case of $A A v$ Ministero dell'Interno. ${ }^{26}$ This ruling specifies that, for the purposes of ascertaining statelessness, a formal act of withdrawal of nationality is not required. ${ }^{27}$ The Court accepted, however, that circumstantial evidence could be used in similar determinations; asking the applicant to provide thorough evidence that no state considered them a citizen would be 'diabolical'. ${ }^{28}$ Statelessness can not only be caused by a formal act of the state of origin, but also by situations which, although not amounting to express administrative acts, result in denial of state protection to the individual. These situations, in which an authority substantially deprives a person of citizenship, can amount to denial of a person's ability to exercise their fundamental rights as recognised under the 1954 Convention, ${ }^{29}$ as well as art 15 of the Universal Declaration of Human Rights. ${ }^{30}$

Furthermore, the Tribunal of Rome dealt with the difficulty of proving TP's status as a stateless person by adopting a protection-oriented approach. ${ }^{31}$ Specifically, as TP was unable to provide direct evidence demonstrating nonpossession of Indian citizenship through a certificate, the Tribunal of Rome

23 Law of 5 February 1992, No 91 'New Rules on Citizenship', 133(38) Gazzetta Ufficiale 1992 (Italy).

24 Until 1950 Tibet was an independent theocratic sovereign state ruled by the Dalai Lama. In that year the People's Liberation Army, headed by the People's Republic of China led by Mao Zedong, invaded Tibet. In 1959 in Lhasa, the People's Liberation Army crushed a revolt forcing the Dalai Lama to flee to India where he formed the Tibetan government in exile. The Tibetan Government in Exile (Central Tibet Administration) has been operating in Dharamsala in India since 1960 and represents the traditional government of Tibet. See Colin P Mackerras, People's Republic of China: Background Paper on the Situation of the Tibetan Population (Report, Writenet and UNHCR February 2005) $<$ https://www.refworld.org/pdfid/423ea9094.pdf >; Hungdash Chiu and June Teufel Dreyer, 'Tibet: Past and Present' (1989) 4(93) Maryland Series in Contemporary Asian Studies 1.

25 See Decreto 23 Giugno 1988 (1989) Giurisprudenza Italiana 699 (Tribunal of Turin).

26 Sentence No 14918 (n 19).

27 ibid.

28 TP $v$ Minister of Home Affairs (n 4) 2.

29 Case No 2242/2013 (First Civil Section, 7 September 2013) (Tribunal of Salerno).

30 Universal Declaration of Human Rights, GA Res 217 A (III), UN GAOR, $3^{\text {rd }}$ sess, $183^{\text {rd }}$ plen mtg, UN Doc A/810 (10 December 1948) art 15.

31 TP v Minister of Home Affairs (n 4) 2-3. 
actively engaged in the search for evidence. ${ }^{32}$ Usually, nationals of a state can easily provide proof of their status through certificates issued by the competent authorities. However, pursuant to art 2697 of the Italian Civil Code, ${ }^{33}$ a stateless person must provide proof demonstrating that they lack citizenship of the state with which they have, or had, significant connections ("whoever wants to assert a right in court must prove the facts that constitute its foundation'). In the case of evidentiary gaps, the principle of attenuation applies to the burden of proof, creating an obligation for the judge to collaborate with the applicant. ${ }^{34}$ Other case law clarifies that the judge could investigate beyond the evidence provided by the parties, as nationality and statelessness are questions of public interest. ${ }^{35}$ Following this trend, some courts, including the Tribunal of Rome in this case, have taken steps to find documentation or request information from the competent administrative authorities. ${ }^{36}$ The Supreme Court of Cassation also strengthened the procedural guarantees for stateless persons by ruling that the judge has an obligation to acquire official information. ${ }^{37}$

\section{CONCLUSION}

TP $v$ The Minister of Home Affairs constitutes an important precedent in the recognition of statelessness for individuals of Tibetan origin, who are born and/or residing in India. The Tribunal of Rome correctly engaged in an investigation of the nationality legislation of India, where TP was born and resided, and Italy, where TP currently lives.

Subsequently, with ANH v Ministero dell'Interno, the Supreme Court of Cassation determined that, where the state refuses to confer individual protections or prerogatives due to nationals, those nationals have the burden of challenging this decision, including by judicial means. ${ }^{38}$ Very often, however, it is difficult, if not impossible, for the person concerned to do so. Clandestinely leaving a state, without adequate documentation, can constitute a crime and their return to the state of origin could place them at risk. The same risk could exist if a person were to go to the embassy of their country. It is also difficult, time-consuming and expensive for a stateless person to take legal action against their state of origin from Italy. The burden is not one that can be met by the applicant; they are unable to properly respond to the material conduct of the state. It is a probatio diabolica against which the judiciary has repeatedly expressed its opposition in the context of ascertaining the status of stateless persons.

32 ibid 3.

33 Royal Decree No 262 of 1942 'Civil Code', art 2697 (Italy).

34 Ministero dell'Interno v AM (First Civil Section, Sentence No 16114, 14 June 2019) (Supreme Court of Cassation) (Italy).

35 Decreto 20 Marzo 1954 (1955) Giurisprudenza 117 (Tribunal of Taranto) (Italy).

36 Decreto 5 Marzo 2003 (n 19), which requested the Italian Ministry of Justice find Cuban legislation on nationality.

37 Sentence No 14918 (n 19).

38 ANH v Ministero dell'Interno (First Civil Section, Sentence No 4257, 4 March 2016) (Supreme Court of Cassation) (Italy). 